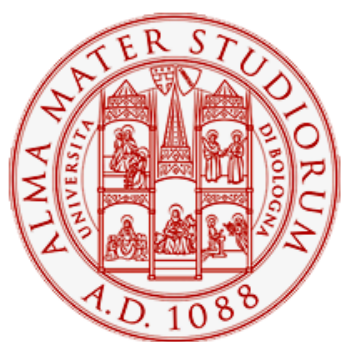

Alma Mater Studiorum - Università di Bologna DEPARTMENT OF ECONOMICS

\title{
Ethnic Concentration, Cultural Identity and Immigrant \\ Self-Employment in Switzerland
}

Giuliano Guerra

Roberto Patuelli

Rico Maggi

Quaderni - Working Paper DSE $N^{\circ} 808$

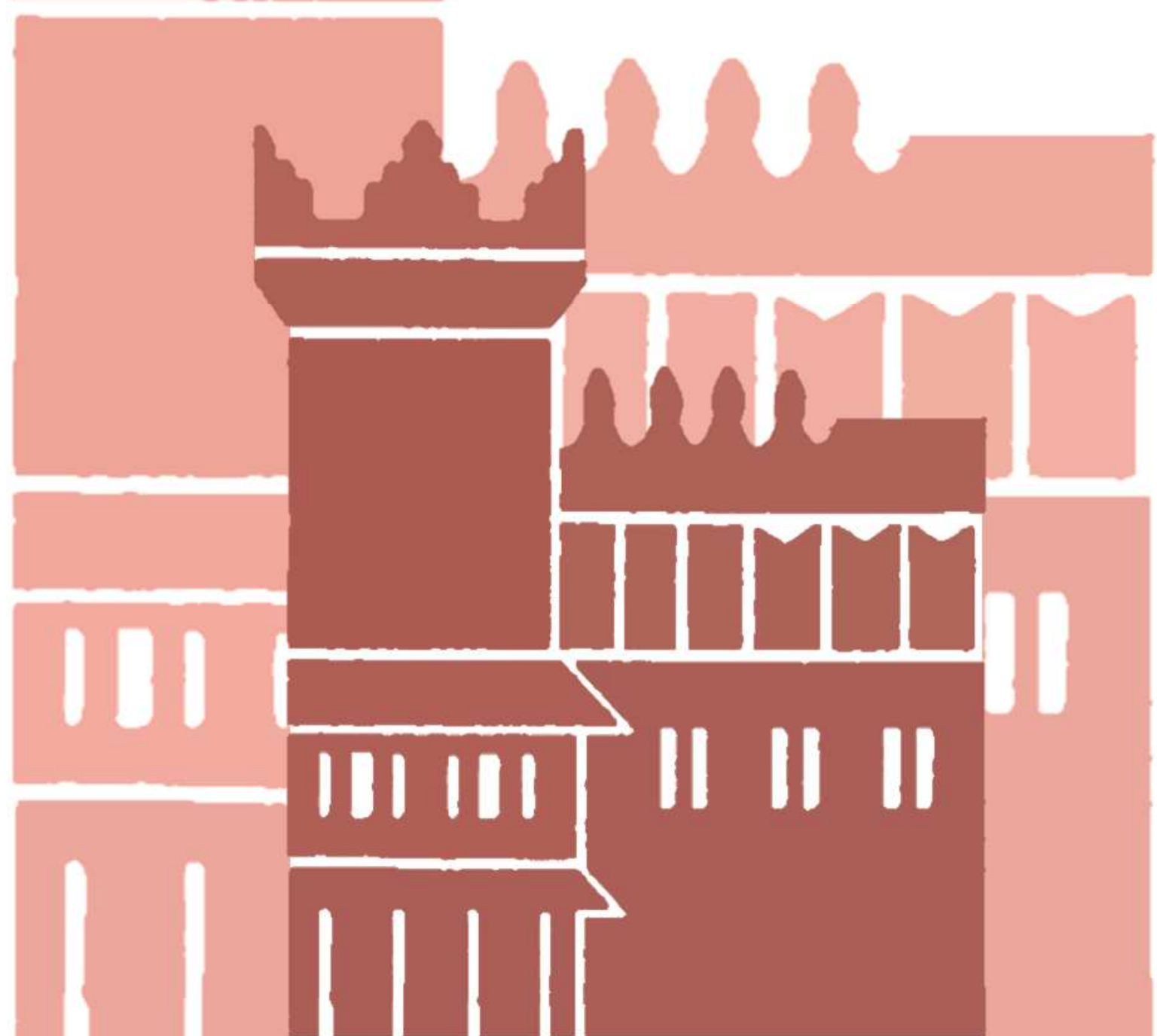




\title{
Ethnic Concentration, Cultural Identity and Immigrant Self-Employment in Switzerland
}

\section{Giuliano Guerra, ${ }^{1}$ Roberto Patuelli, ${ }^{2}$ Rico Maggi ${ }^{1}$}

\author{
${ }^{1}$ Institute for Economic Research (IRE), University of Lugano, Switzerland. E-mails: giuliano.guerra@usi.ch; \\ rico.maggi@usi.ch \\ ${ }^{2}$ Department of Economics, Faculty of Economics-Rimini, University of Bologna, Italy; The Rimini Centre for \\ Economic Analysis (RCEA), Italy. Email: roberto.patuelli@unibo.it
}

\begin{abstract}
Immigrant self-employment rates vary considerably across regions in Switzerland. Business ownership provides an alternative to wage labour, where immigrants have to face structural barriers such as the limited knowledge of the local language, or difficulties in fruitfully making use of their own human capital. Despite their historically high unemployment rates with respect to natives, immigrants in Switzerland are less entrepreneurial. It is therefore important to uncover factors that may facilitate the transition from the status of immigrant to the one of economic agent. Among others factors, concentration in ethnic enclaves, as well as accumulated labour market experience and time elapsed since immigration, have been associated to higher business ownership rates. In this paper, we use a cross-section of 2,490 Swiss municipalities in order to investigate the role played by the ethnic concentration of immigrants, as well as cultural factors, in determining self-employment rates.
\end{abstract}

Keywords: self-employment, immigrants, Switzerland JEL codes: C21, J24, J61, O15, R23 


\section{Introduction}

Since the 1960s, sociological and economic research on the determinants of ethnic entrepreneurship has attempted to explain why immigrants in advanced economies are more likely to become self-employed than natives, and more generally, why some ethnic groups show higher self-employment rates. ${ }^{1}$ Early-stage research pointed out that structural factors like ethnic exclusion and discrimination widely contribute to explain why immigrants turn to self-employment (Bonacich, 1973; Wong, 1988). Later on, differences in education and work experience of immigrants have been emphasized. Results hold for many countries, including Australia, Canada and the United States (Reimers, 1983; Evans \& Kelley, 1986; Bloom et al., 1995). However, human capital does not provide a full explanation for such remarkable differences. For instance, ecological approaches stressed the importance of factors such as ethnic and cultural diversity, as well as fluency in the host country's language, in encouraging or displacing business ownership.

The academic discussion on ethnic entrepreneurship has gained much more attention after the works of Borjas (1986) and Evans (1989), which shed light on two important results. The first is that immigrants tend to be more entrepreneurial in areas where other individuals of the same ethnic group are concentrated. Measured by Borjas as the proportion of foreigners on the total population of US metropolitan areas, the effect of ethnic enclaves on business ownership is positive, suggesting that concentration in specific geographic areas enhances opportunities for immigrants to become self-employed. In fact, immigrants located in ethnic enclaves benefit from comparative advantages in serving the needs of consumers of the same ethnic group according to the 'protected market hypothesis' (Light, 1972), even if the results for different groups are mixed. Furthermore, the size of the immigrant group also provides some explanation for differences in self-employment propensity. Immigrants belonging to very large groups are more likely to be entrepreneurs than immigrants from very small groups (Evans, 1989). This first result has a precise implication in terms of policy: cities with larger ethnic communities produce more entrepreneurs, thus offering immigrants a way to overcome structural barriers on the labour market (Zhou, 2004). Furthermore, business ownership might provide an alternative to wage employment for immigrants, generally increasing their job satisfaction ('self-employment out of dissatisfaction', see Noorderhaven et al., 1999) and employment chances ('self-employment out of unemployment'). Still, the potential for growth of ethnic businesses have been shown to be very limited (Aldrich et al., 1983; Mohl, 1983).

The second important result is that immigrants are influenced in their employment decisions by belonging to ethnic groups which are not fluent in the language spoken by natives. Using Australian data, Evans (1989) finds that immigrants with a large percentage of the group not fluent in English are more likely to be entrepreneurs. However, evidence from the US suggests the opposite: those with English language difficulties are less likely to be business owners (Fairlie \& Meyer, 1996; Portes \& Zhou, 1996). Given these controversial results and the policy relevance of the linguistic characteristics of immigrants, further research is needed on this matter.

In recent years, the academic community has shown a decreasing interest in decisions regarding selfemployment, although it represents an important component of the immigrant experience in many labour markets, as well as a way to overcome isolation and discrimination. Both in the presence of push effects (self-

Even if self-employment and entrepreneurship are not the same, the literature does not agree on a clear definition of 'entrepreneurs' and 'self-employed' (see, for a brief discussion, Aldrich \& Waldinger, 1990). In this paper, we will refer to immigrant self-employment and business ownership as surrogates for ethnic entrepreneurship. 
employment as an alternative to wage- and un-employment) and pull effects (the existence of ethnic markets and opportunities), self-employment remains a central policy issue in determining economic progress and integration of immigrant minorities.

With more than 20 per cent of the overall active population made up by immigrants, Switzerland is one of the countries with the largest foreign population. Since 1970, the Federal Government has attempted to manage immigration flows in order to soften the ongoing conflict between economic needs (chronic excess labour demand) and political pressure from nationalistic groups aiming to reduce the level of foreign population (Gross, 2006). In this regard, the integration of immigrants has gained much attention in the political debate. Switzerland is also known for high wages, good working conditions and historically low unemployment rates, which attract workers from all over the world. Even if immigrants benefit from the overall good job environment, their unemployment rates are persistently above those of the Swiss citizens, both for women ( 9.1 per cent against 3 per cent in 2003) and for men (7.2 per cent against 2.8 per cent) (OECD, 2009). If compared with other OECD countries, looking only at male active population, the gap between native and immigrant unemployment is rather consistent: in 2003, the unemployment rate of immigrants was 2.6 times higher than that of the natives, against a 1.6 factor for the OECD in a whole. Only the Netherlands, Norway and Belgium show higher gaps.

Despite the (relatively) high unemployment rates, which tend to persist over time, immigrants in Switzerland are less likely to become entrepreneurs than the natives. Self-employment rates of foreign-born individuals are lower than those observed among Swiss citizens (in 2000, 5.6 per cent of the total immigrant labour force against 12.3 per cent among the natives). Evidence collected in the US by Yuengert (1995), in contrast, reports a selfemployment rate of immigrants (11.7 per cent) higher than the one of natives ( 8.3 per cent). Similarly, in the UK, the 1991 Census of Population reported that non-whites had a self-employment rate of 14.6 per cent, compared to 12.3 per cent for whites (Clark \& Drinkwater, 2000).

We can think of two reasons for which immigrants are less entrepreneurial than the natives. Firstly, one might argue that Swiss regions are too small to provide sufficiently large ethnic markets for potential ethnic entrepreneurs. Secondly, despite the high number of immigrants, migration flows towards Switzerland used to be strictly regulated. ${ }^{2}$ As a result, Switzerland has turned into a multicultural and multilinguistic country, far beyond the traditional divisions in the three linguistic regions. Traditional and recent immigration waves ${ }^{3}$ contributed to shape a rather heterogeneous and fractionalized ethnic environment, which in some cases might have prevented immigrants from benefiting from the presence of their coethnics, for instance in helping them to tackle bureaucracy, or in providing market incentives to open a business. Heterogeneity between Swiss regions is particularly evident in terms of the linguistic gap, which breaks the country in three main linguistic and cultural areas: German, French, and Italian. Natives share the language with the country from which they are surrounded, namely Germany to the North, France to the West, Italy to the South, and Austria and Liechtenstein to the East.

2 In fact, they were predominantly 'driven' by economic need. For instance, during the post-war economic boom, Italian immigrants were mainly recruited for low-skilled jobs in the construction, textile and machinebuilding sectors. Initially, they were entitled to stay for just one year, and permanent permits could be obtained only after a period of ten years. Since the late 1960s, Italians have been followed by workers from Spain, Portugal, the former Yugoslavia, Turkey and many other countries, while immigration policies have become less strict. The inflows of workers from economically less developed countries have reduced the overall skill level of immigrants (Fluckiger \& Zarin-Nejadan, 1994).

3 It should be noted that we refer to first immigration waves (Italians, Germans and French) as traditional ones, while immigrants belonging to more recent waves (i.e., the Spanish, Portuguese, Yugoslavians and the Turkish) are referred to as recent. 
From 1970 to 1990, the Federal Government used to fix annual quotas for the number of new permits released to foreign workers, which used to be allocated according to the needs of firms, and proportionally to the population of each canton (the main regional entity in Switzerland). The distribution of these permits was subsequently organized by local authorities (municipalities), which nowadays show substantially different ethnic compositions. Since self-employed immigrants are expected to serve their ethnic community, which is locally concentrated, we also observe important differences in self-employment rates, which differ widely within the country. It is therefore important to uncover the local determinants that may facilitate the transition from the status of immigrant to the one of economic agent/entrepreneur.

The aim of this paper is to uncover the influence of ethnic concentration and cultural characteristics on the self-employment rates of immigrants. We use data for a cross section of 2,490 Swiss local units (municipalities) collected by the Federal Population Census (FPC) in 2000. We evaluate the effects on self-employment rates of immigrants that are associated with an ethnic concentration index and with the characteristics of the dominant ethnic group, with respect to the country of origin and its proficiency in the host region's language. We show that highly concentrated ethnic communities have higher immigrant self-employment rates. This is particularly true for local ethnic communities which are dominated by groups of traditional origin or speaking the same language as the natives (German, French or Italian, according to the region).

The paper is organized as follows. In Section 2, we present a model for the determinants of immigrant selfemployment rates. In Section 3, we describe the data employed in our analysis and we examine preliminary statistical features. In Section 4, we present our findings for Switzerland. Section 5 concludes the paper by discussing current open research questions and further refinements of our model.

\section{The Model}

The model addresses the aggregate behaviour of a local multiethnic community of foreign workers who individually decide between self-employment and paid work, given a set of characteristics. We do not make direct inference on individual behaviour, since this has been thoroughly investigated in the literature and would require micro-level data (for an overview, see Zhou, 2004), nor we look at wage/earnings differentials between the two options.

The aim of this paper is to uncover the role played by the immigrant pool attributes and the local unit's characteristics in determining business ownership. We measure self-employment among immigrants as the share of self-employed on the overall foreign active population. As local conditions, we refer to the average characteristics of the multi-ethnic pool (gender, age, family, education, ethnic concentration, residential status, language integration, working status composition) and to the characteristics of the local unit (population density, geographic remoteness, linguistic region). In particular, we assume that there are effects on the local level of immigrant self-employment due to ethnic concentration, that is, to the presence of a dominant ethnic group within the area.

From a microeconomic perspective, it may be optimal for an individual to build economic relationships preferentially with other individuals of the same ethnic group (Glaeser et al., 2000; Alesina \& La Ferrara, 2002; for a formal discussion of transaction costs in a multiethnic society, see also Lazear, 1999). From a more general 
perspective, ethnic concentration may be favourable to business ownership since it reduces conflicts and prejudices, and thus uncertainty. Furthermore, the dominance of an ethnic group increases the pool of ideas, needs, human resources and capitals within the local unit, as well as the opportunities for its members to capture and activate those resources. The presence of an ethnic social capital it is often referred to as a key determinant in immigrant business creation (Aldrich \& Waldinger, 1990). On the other hand, a concentrated ethnic community might be less suitable than a diverse one to enhance productivity and innovation, since the melting pot ensures the mix of abilities, cultures and thoughts that is at the basis of creativity and actual problem-solving processes (for an overview, see Alesina \& La Ferrara, 2005).

We test the ethnic concentration hypothesis with regard to the seven main ethnic groups which we expect to affect the self-employment propensity of immigrants. The selected groups (Italians, Germans, French, Portuguese, Spanish, Turkish and former Yugoslavians) account for almost three quarters of the entire foreign active population in Switzerland, but show substantial differences in self-employment rates. For this reason, we discriminate local units where the dominant nationality belongs to the groups of recent immigration. We expect those communities to be less integrated and more fragile, as their social networks are not completely developed so as to encourage them towards self-employment. Recent immigrants often lack first-hand knowledge, experience and capitals to start an economic activity on their own, since they need to accumulate savings and establish credit in order to obtain financing.

In addition, we control for local units where the dominant nationality is formed by immigrants of the same linguistic group as the natives. On the one hand, immigrant groups which are not proficient in the language spoken locally may be more likely to show high self-employment rates, as suggested by the isolated labour pool and disadvantaged theory (Light, 1979; Evans, 1989). On the other hand, linguistic integration could also encourage self-employment because of cultural proximity. Speaking the same language as the natives could provide immigrants with more business opportunities.

The diffusion of self-employment among immigrants, specified as the share of self-employed immigrants over the immigrant active population, is then modelled as a function of: (1) ethnic concentration; (2) the characteristics of the immigrant community, evaluated at the average and related to family, labour market and human capital features; (3) a set of control variables for geographic and linguistic characteristics of the local unit. While Table 1 provides definitions of the variables included in the model, the following subsections discuss their relevance in detail.

\subsection{Ethnic Concentration Variables}

We examine how ethnic concentration of the local immigrant pool affects local self-employment rates. The dominance of a particular ethnic group may be expected to encourage self-employment through increased social interaction and the rise of specific needs, ideas and resources that a sparse minority cannot otherwise ensure. We use an adaptation of the Herfindahl-Hirschman Index (HHI) (Hirschman, 1945; Herfindahl, 1950), usually used as a measure of trade or industrial concentration, in order to measure ethnic concentration of the seven proposed groups of immigrants. 
Table 1. Definition of variables

\begin{tabular}{|c|c|}
\hline Variable definition & Variable name \\
\hline $\begin{array}{l}\text { Local Immigrant Self-employment Rate } \\
=\text { Immigrant Self-Employees } / \text { Immigrant Active Population }\end{array}$ & FOREMPSE \\
\hline $\begin{array}{l}\text { Ethnic Concentration Variables } \\
\text { Herfindahl-Hirschman Index of Ethnic Concentration (Eq. (1)) } \\
\text { Dominant Ethnic Group, of Recent Immigration }=1 \text {, Otherwise } 0 \\
\text { Dom. Ethnic Gr., Same Language as Region }=1 \text {, Otherwise } 0\end{array}$ & $\begin{array}{l}\text { HERFINDAHL } \\
\text { RECENTIMMIGR } \\
\text { LANGPROALL }\end{array}$ \\
\hline Characteristics of the Immigrant Active Population in the Local Unit & \\
\hline $\begin{array}{l}\text { Share of Male Immigrants } \\
=\text { Immigrant Active Men / Immigrant Active Population }\end{array}$ & FORACTIVEMEN \\
\hline $\begin{array}{l}\text { Share of Married Immigrants } \\
=\text { Immigrant Active Married / Immigrant Active Population }\end{array}$ & FORACTIVEMARRIED \\
\hline $\begin{array}{l}\text { Share of Immigrants with a Non-Permanent Residence Permit } \\
=\text { Immigrant Active Non-Permanent Residents/Immigrant Active Population }\end{array}$ & FORACTIVENON \\
\hline $\begin{array}{l}\text { Share of Immigrants Employed in Services } \\
=\text { Immigrant Employees in Services / Immigrant Employees }\end{array}$ & FOREMPTER \\
\hline $\begin{array}{l}\text { Average Age of Immigrants } \\
=(\text { Sum of Immigrant Actives * Age (in Years) }) / \text { Immigrant Active Population }\end{array}$ & FORACTIVEAGE \\
\hline $\begin{array}{l}\text { Average Family Size of Immigrants } \\
=(\text { Sum of Immigrant Actives * Family Size }) / \text { Immigrant Active Population }\end{array}$ & FORACTIVECHIL \\
\hline $\begin{array}{l}\text { Share of Immigrants with a Professional Degree } \\
=\text { Immigrant Active with Professional Degree/ Immigrant Active Population }\end{array}$ & FORACTIVEPROFEDU \\
\hline $\begin{array}{l}\text { Share of Immigrants with an Academic Degree } \\
=\text { Immigrant Active with Academic Title / Immigrant Active Population }\end{array}$ & FORACTIVEACCAEDU \\
\hline $\begin{array}{l}\text { Unemployment Rate of Immigrants } \\
=\text { Immigrant Unemployed / Immigrant Active Population }\end{array}$ & FORUNEMP \\
\hline Controls for Geography & \\
\hline Urban Dummy, City $=1$, Otherwise 0 & URBAN City \\
\hline Urban Dummy, Suburb $=1$, Otherwise 0 & URBAN Suburb \\
\hline Minimum Altitude & ZMIN \\
\hline
\end{tabular}

In our data set, the HHI ranges from 0 to 1.0, where 0 implies no concentration and 1 means that there is a single immigrant group (among the seven considered) within the local unit. For each local unit $i(i=1, \ldots, N)$, we compute the HHI as:

$$
H H I_{i}=\sum_{k=1}^{7} s_{i, k}^{2},
$$

where $s_{i, k}$ is the share of immigrants of the $k$ th ethnic group (among the seven groups selected) on the immigrant active population living in local unit $i$.

In addition, we expect some differences in self-employment to arise in local ethnic communities where the dominant group is constituted by newcomers. Since we do not have data on time elapsed since immigration or on the labour market experience of immigrants, we single out those communities for which there is a dominance of newcomers as pools of recent immigration, as a proxy for limited experience on local labour markets. A dummy variable is used to assess whether or not the local units meet this characteristic.

Finally, we account for the linguistic integration of immigrants, that is, whether or not the locally dominant ethnic group speaks the same language as the natives. We expect groups which are proficient in the host region's language to be more effective in rising human/financial resources and in becoming business owners (for example, it may be easier for them to tackle bureaucratic issues or serve/interact with the natives). Language 
proficiency is proxied with a dummy variable that takes the value of 1 if the dominant nationality belongs to the same linguistic group as the locals, and 0 otherwise.

\subsection{Characteristics of the Immigrant Active Population in the Local Unit}

The model tests the effects of additional local immigrant pool characteristics, namely education, gender, size of the family and age, on self-employment rates. The overall level of education attained is expected to positively influence the share of self-employed immigrants within the local unit. On the one hand, education - and more generally human capital - is traditionally associated with business longevity and success (Kim \& Won Moo, 1985; Yoon, 1991; Bates, 1994), since it is assumed to increase the set of skills enabling individuals to assess market opportunities and to improve their organizational and managerial ability (Borjas, 1986). On the other hand, immigrants with higher educational attainments should be better equipped for collecting resources within their family and their ethnic community (Sanders \& Nee, 1996). Our analysis uses two measures of education: the share of professionally educated immigrants (on the overall immigrant active population), and the share of immigrants with academic education. This distinction is made because we expect the former to have accumulated more job experience, both within their home country and in Switzerland.

In addition, the gender composition of the immigrants, as well as their average age - in quadratic form to catch nonlinearities ${ }^{4}$ - are added as control variables. We expect a positive effect of the share of men and of the average age of the immigrants on self-employment, since men are more likely to start a business (because they are less risk averse and more continuative in their work experience than women), as well as older persons, at least until a certain age. Marital status is added as well, in order to control for the incidence of family. Between immigrants who have a family, we may expect to observe risk averse behaviour, which would reduce the selfemployment rate within the immigrant pool. ${ }^{5}$ The average size of the immigrant household provides a picture of the cultural milieu, with larger families disposing of fewer capitals and being characterized by a higher risk aversion, thus being less attracted by business ownership. ${ }^{6}$ We expect a negative effect of this variable on selfemployment rates.

We also control for the share of non-permanent residents within the local community, since a less stable workforce, often linked to a seasonal or temporary job, is assumed to be less predisposed towards business ownership. The local industry mix is taken into account by the share of immigrants employed in services. We expect a positive effect on self-employment incidence since it has been shown that immigrants employed in trades, sales and managerial occupations are more likely to turn to self-employment (Borjas, 1986; Le, 2000).

As for the occupational status of immigrants, the literature usually refers to unemployment as an ambiguous determinant of self-employment. On the one hand, high unemployment regions may experience high rates of immigrant self-employment because of the option that business ownership offers to immigrants who do not have a job ('self-employment out of unemployment'), suggesting a positive relationship with self-employment. On the

4 Age is specified in a quadratic form to control for the possibility that turning into self-employment may increase at a diminishing rate with age (Sanders \& Nee, 1996).

5 However, early empirical research at the micro level highlighted a positive relationship between being married and being self-employed (Borjas, 1986), because of the increased ability of married persons to collect help among familiars.

6 Larger families may also profit from members working - often for free - within the business. However, we expect this result to be less important in Switzerland, where wages and working conditions are under strict surveillance. 
other hand, low unemployment regions could provide immigrants with potentially wider ethnic markets, thus increasing their opportunity to become self-employed, for example in migrant-related services (phone centres, ethnic shops, etc.). In this case, an inverse relationship with self-employment could be expected. ${ }^{7}$ For these reasons, we include in the model the immigrant unemployment rate, in quadratic form to catch nonlinearities. Because the nature of the relationship between unemployment and self-employment is controversial, we let the data speak, and we do not formulate a specific sign expectation.

\subsection{Controls for Geography}

Additional variables, identifying the characteristics of the local units, have been added to control for geographical differences. A possible urban-rural gap is captured by a categorical variable which splits our crosssection in: cities, suburbs and rural units, the latter being the reference level. Urban areas are expected to increase the propensity of the immigrants to be self-employed, according to a market view hypothesis (Le, 2000). Furthermore, the urban-rural distinction is expected to capture unobserved urban characteristics such as land price, firm size, urban density, and central or peripheral location. For this reason, interpretation of the urban-rural estimated coefficients should be given with care. The average distance between municipalities, that is, whether the area is easily linked to other areas or is rather isolated (as is the case for the municipalities in the Alpine region) is proxied by the minimum altitude of the areal unit.

Our model can be generically expressed as follows:

$$
y_{i}=\alpha+\beta_{1} H H I_{i}+\beta_{2} D_{1, i}+\beta_{3} D_{2, i}+\sum_{k} \gamma_{k} X_{k, i}+\varepsilon_{i},
$$

where: $y_{i}$ is the share of self-employed immigrants over the immigrant active population, for each local unit $i$; $H H I_{i}$ is the ethnic concentration index; $D_{1, i}$ and $D_{2, i}$ are the dummy variables for recent immigration and language proficiency; $X_{k, i}$ is the $k$ th control variable; and $\varepsilon_{i}$ is the error term.

\section{Data}

The data used in this paper are drawn from the Swiss Federal Population Census (FPC) of 2000 (FSO, 2000). The data set includes population variables (citizenship, country of origin, place of residence, position in the household, education, profession, age, gender, etc.) and household data (number of individuals living in the household, etc.). ${ }^{8}$ Additional variables controlling for geography, as well as geo-referenced data for local units, are provided by the Swiss Federal Statistical Office (FSO, 2001, 2004).

7 Empirical evidence, based on individual-level entry rates and duration models, is also mixed (for an overview, see Glocker \& Steiner, 2007).

8 Participation in the census is compulsory and reached 99.87 per cent of the population. Unlike many censusbased studies, we have a virtually full population sample, although unfortunately, the FPC does not provide any information on wages. 
The basic unit of analysis is the local unit (municipality), including - after the exclusion of the municipalities with less than five immigrant workers $-2,490$ observations. ${ }^{9}$ The definition of residents of a particular area is given by the Federal Statistical Office after the concept of economic domicile, that is, by looking at where they work or attend school four at least four days per week without commuting to another local unit. All immigrantrelated variables are available at the municipality level and shares are computed dividing by the immigrant active population of the area. ${ }^{10}$ The sectoral distribution of immigrants is proxied by the share of immigrants employed in services. The definition of immigrant groups is based on the country of origin (nationality), and all immigrants are non-citizens. Naturalized foreigners are not considered as immigrants, since the naturalization process, which is voluntary, usually takes at least 12 years - unless it is carried out through a facilitated naturalization procedure $^{11}$ - and requires approval at the federal, cantonal and municipal levels, making the procedure very slow and its effects rather marginal. In our data set, self-employed immigrants are defined as independent foreign workers, both full and part-time.

Table 2 reports descriptive statistics for our data set. Immigrant self-employment rates are relatively low (8 per cent), compared with those of the natives (whose average - not reported - is 15.4 per cent). Extreme values extend to the full possible range of the variable (from 0 to 100 per cent), but can only be found for scarcely populated local units. The numerator and denominator of the immigrant self-employment rates are reported as well, to show the high heterogeneity in the size of our local units. With regard to the explanatory variables, the HHI for ethnic concentration has an average of 0.2459 and ranges from 0 to 1 . Male immigrants account on average for 60 per cent of the labour force, which is predominantly married (69 per cent). The share of nonpermanent residents on the immigrant active population is very small (4.3 per cent on average), suggesting that most immigrants are in Switzerland on a stable basis. Moreover, highly educated immigrants (those having a professional or an academic education degree) are still a minority in the Swiss labour market (jointly, they account for about 20 per cent of the foreign active population), while the average immigrant unemployment rate is quite large (6.8 per cent) compared to the one of Swiss citizens (2.2 per cent, not reported). Finally, as it is shown in the final rows of Table 2, the local immigrant population stretches from a minimum of 5 to a maximum of 106,386, recorded in Zurich, which is also the main Swiss city in terms of overall population $(363,273)$.

Figure 1 shows the geographical distribution of immigrant self-employment rates. Unsurprisingly, selfemployment rates among foreigners differ widely within the country. High rates are registered close to the border with Italy, in the Italian-speaking part, and close to France, in the French-speaking part. Low selfemployment rates are recorded over the Alps or scattered across the dominant German-speaking region. On a purely descriptive basis, border regions seem to offer better conditions for self-employment among immigrants.

9 Since we have a high variation in the dimension of the local immigrant population, we eliminate all local units that are below 5 foreign workers. This data reduction significantly increases the quality of our findings, without losing too much information (we eliminate 406 out of 2,896 local units).

10 In the absence of place-of-birth information in our data set, we will refer to all non-citizens as foreign-born and to nationals as natives. The non-citizens are both permanent residents (permit $\mathrm{C}$ ) and non-permanent ones (permit B), where the former requires less restrictive conditions to open a business. In principle, permits of type $\mathrm{B}$ give the possibility to obtain a $\mathrm{C}$ permit after a period of 5-10 years. Active population is defined as the number of inhabitants that at the time of the interview (5 December 2000) were employed or unemployed.

11 Facilitated naturalization, that should meet some legal requirements, benefits in particular foreign spouses of Swiss nationals and children of a Swiss parent who do not yet hold Swiss nationality (Federal Office for Migration). 
Apart from this, the picture does not provide a clear spatial pattern other than immigrant self-employment not being an urban phenomenon (the main cities show average rates).

Table 2. Descriptive statistics

\begin{tabular}{|c|c|c|c|c|c|c|}
\hline & Mean & Stdev & Min & 1.Quart. & 3.Quart. & Max \\
\hline $\begin{array}{l}\text { Self-employment rate of immigrants } \\
\text { (dep) }\end{array}$ & 0.0797 & 0.0753 & 0.00 & 0.04 & 0.10 & 1.00 \\
\hline Self-employed immigrants (num) & 18.3590 & 102.1522 & 0.00 & 1.00 & 13.00 & $3,310.00$ \\
\hline $\begin{array}{l}\text { Immigrant active population } \\
\text { (denom) }\end{array}$ & 358.3500 & $2,033.9000$ & 5.00 & 20.00 & 223.00 & $69,937.00$ \\
\hline $\begin{array}{l}\text { Herfindahl-Hirschman index of } \\
\text { ethnic concentration (hhi) }\end{array}$ & 0.2459 & 0.1405 & 0.01 & 0.16 & 0.30 & 1.00 \\
\hline Share of male immigrants & 0.6145 & 0.0928 & 0.18 & 0.57 & 0.66 & 1.00 \\
\hline Share of married immigrants & 0.6902 & 0.1051 & 0.00 & 0.64 & 0.74 & 1.00 \\
\hline $\begin{array}{l}\text { Share of immigrants with a non- } \\
\text { permanent residence permit }\end{array}$ & 0.0428 & 0.0801 & 0.00 & 0.00 & 0.05 & 1.00 \\
\hline $\begin{array}{l}\text { Share of immigrant employed in } \\
\text { services }\end{array}$ & 0.4939 & 0.1554 & 0.00 & 0.39 & 0.60 & 1.00 \\
\hline Average age of immigrants & 37.5390 & 3.0064 & 25.50 & 35.76 & 39.15 & 52.38 \\
\hline Average family size of immigrants & 3.1262 & 0.5438 & 1.56 & 2.81 & 3.41 & 8.50 \\
\hline $\begin{array}{l}\text { Share of immigrants with a } \\
\text { professional degree }\end{array}$ & 0.1088 & 0.0805 & 0.00 & 0.06 & 0.14 & 0.60 \\
\hline $\begin{array}{l}\text { Share of immigrants with an } \\
\text { academic degree }\end{array}$ & 0.0934 & 0.0923 & 0.00 & 0.03 & 0.13 & 0.60 \\
\hline Unemployment rate of immigrants & 0.0676 & 0.0579 & 0.00 & 0.03 & 0.09 & 0.69 \\
\hline Minimum altitude & 524.1000 & 207.3300 & 192.00 & 406.00 & 592.00 & 1791.00 \\
\hline Immigrant population & 600.0293 & $3,240.1270$ & 5.00 & 33.00 & 377.25 & $106,386.00$ \\
\hline Overall population & $2,898.2740$ & $10,473.4200$ & 38.00 & 500.00 & $2,655.70$ & $363,273.00$ \\
\hline
\end{tabular}

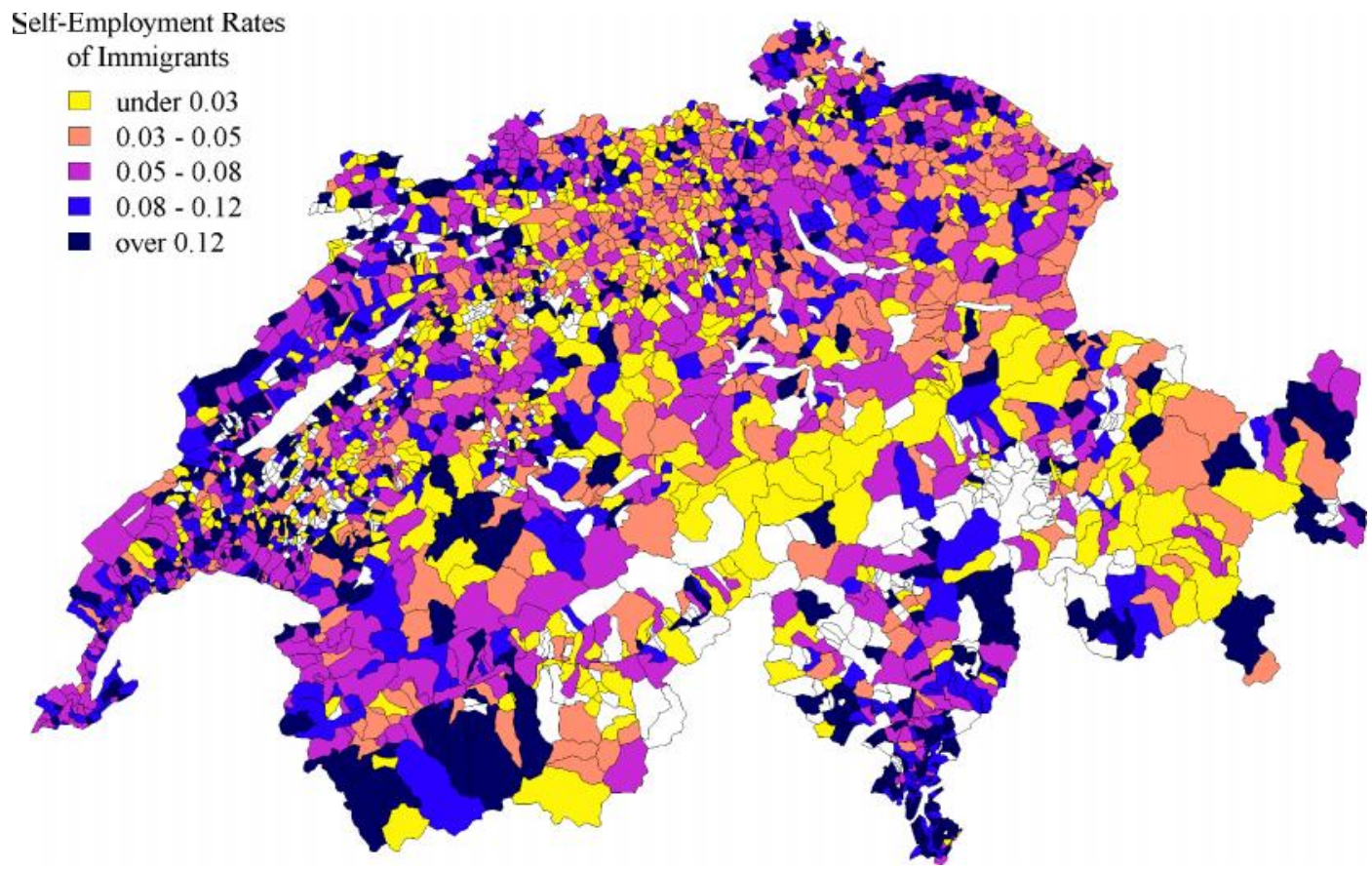

Figure 1. Immigrant self-employment rates by local unit 
Figure 2 depicts the shares of immigrants on the overall local population. The spatial distribution observed is rather different from the previous one. High shares of immigrants are registered in the Lake of Geneva region, in the Zurich area and in the South (the Canton of Ticino). Low shares are recorded in the rural region of the Cantons of Bern and Fribourg.

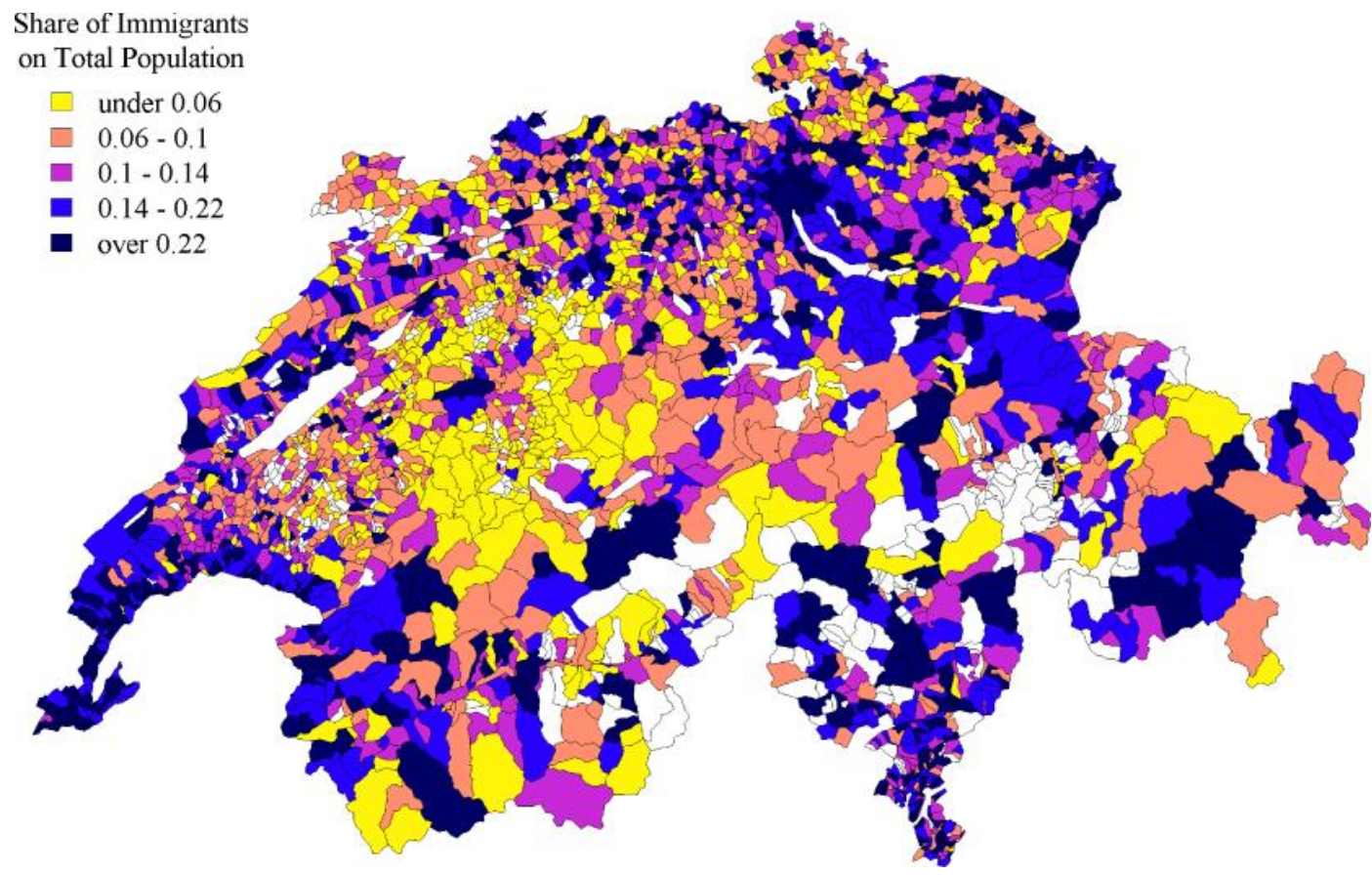

Figure 2. Shares of immigrants on overall population by local unit

Since in our analysis we use HHI values for the Swiss municipalities as a proxy for the ethnic concentration of immigrants, we are interested in observing how this variable is distributed in space (Figure 3). Dominance of a particular immigrant group is registered in the South - the Italian-speaking region - and in the rural areas of the German-speaking part. Low HHI values are recorded within and around the main cities (Geneva, Bern, Basel and Zurich), which attract different nationalities.

In terms of ethnic background, the presence of the selected ethnic groups on the total immigrant population vary substantially at the regional level (Figure 4). The former Yugoslavians are dominant in the Germanspeaking part - the Middle Land and the North-East; the Italians constitute the main group in the region close to the border with Italy and in the suburbs of the main cities in the Middle Land (Bern, Basel, Zurich); the Portuguese are leading in the French-speaking part, especially around the Geneva Lake (the West). Italians are, except for the Italian-speaking Canton of Ticino, where they are dominant, the second-biggest group in most areas (not shown). The French and the Germans are relevant in some areas of their language-related region. 


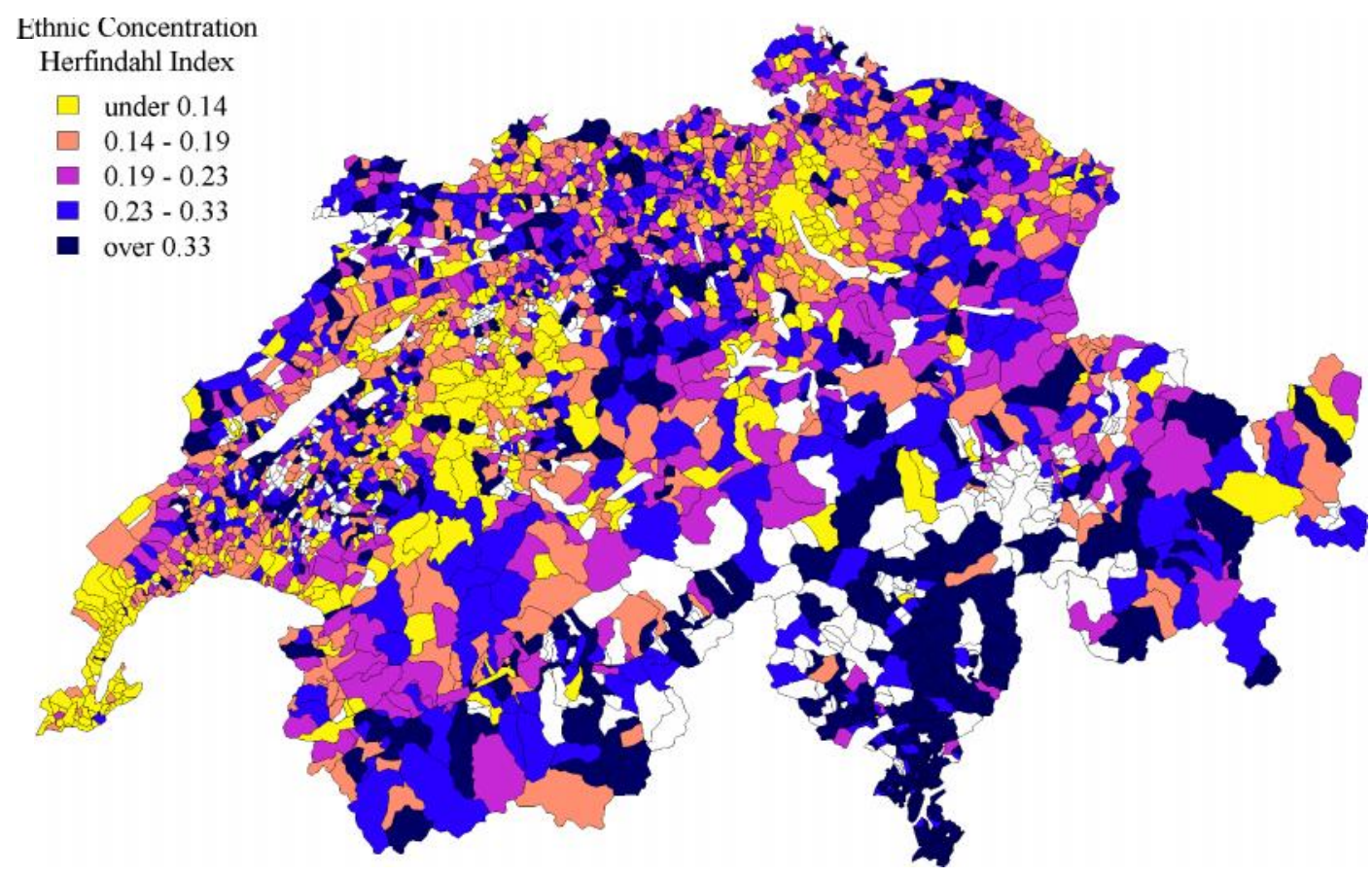

Figure 3. HHI ethnic concentration index by local unit

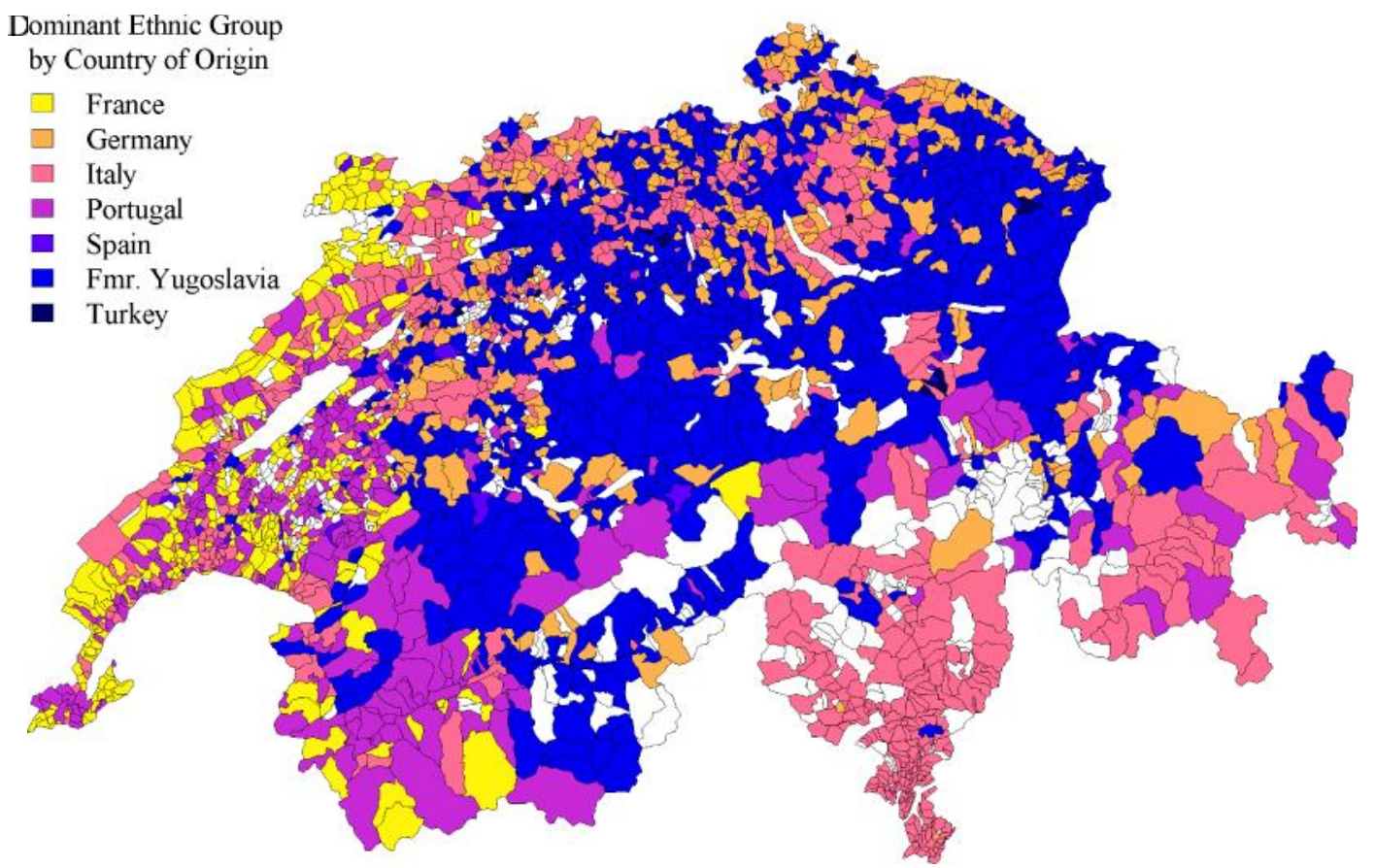

Figure 4. Dominant nationality by local unit

Table 3 presents selected descriptive statistics for the seven largest groups of immigrants, as well as for Swiss citizens. Among these groups, immigrants coming from the former Yugoslavia are the second-biggest pool (21 per cent of the overall immigrant active population) after the Italians ( 23 per cent). Self-employment rates of immigrants are significantly lower than the one observed for the natives, in particular for the groups of more recent immigration. Immigrants from Germany ( 9.3 per cent), Italy ( 7.5 per cent) and France (8.4 per cent), 
instead, show above-average self-employment rates. Unemployment hits severely the former Yugoslavians, the Turkish and immigrants of other nationalities ('Others'). Taken as a whole, immigrants face much higher unemployment rates than the natives ( 8.1 per cent against 2.8 per cent), and with the exception of the Portuguese and the Spanish, groups with higher self-employment rates appear to show lower-than-average unemployment rates.

Table 3. Selected descriptive statistics by ethnic background

\begin{tabular}{lllll}
\hline Group & $\begin{array}{l}\text { Share on overall active } \\
\text { population }\end{array}$ & $\begin{array}{l}\text { Share on immigrant } \\
\text { active population }\end{array}$ & $\begin{array}{l}\text { Self-employment } \\
\text { rate }\end{array}$ & $\begin{array}{l}\text { Unemployment } \\
\text { rate }\end{array}$ \\
\hline Natives & 0.7835 & & 0.1234 & 0.0278 \\
Immigrants & 0.2165 & 1.0000 & 0.0564 & 0.0812 \\
- Italians & & 0.2303 & 0.0753 & 0.0512 \\
- Fmr. & 0.2106 & 0.0288 & 0.1143 \\
$\quad$ Yugoslavians & & & 0.0250 & 0.0445 \\
- Portuguese & 0.1086 & 0.0927 & 0.0315 \\
- Germans & 0.0860 & 0.0423 & 0.0456 \\
- Spanish & 0.0664 & 0.0483 & 0.1487 \\
- Turkish & 0.0467 & 0.0841 & 0.0545 \\
- French & 0.0454 & 0.0619 & 0.1221 \\
- Others & 0.2528 & & \\
\hline
\end{tabular}

Source: 2000 FPC.

\section{Empirical Application}

We estimate, for 2,490 Swiss municipalities, a model for the rates of immigrant self-employment, which we assume to be influenced by the level of ethnic concentration, measured by the Herfindahl-Hirschman Index, by the time elapsed since immigration - proxied by a dummy variable indicating whether or not the locallydominant nationality is of recent (rather than traditional) immigration - and by the proficiency in the host region's language - also proxied by a dummy variable for whether or not the dominant nationality belongs to the same linguistic group of the natives. As additional covariates, we use a set of control variables describing the characteristics of the local immigrant population and the geographic and linguistic characteristics of the local units, as discussed in Section 2.

Since our dependent variable - the share of immigrant self-employed - is a ratio, it is convenient to estimate our model in a logistic regression framework, so as to explicitly account for the constrained nature of the variable analysed. By doing so, we identify the numerator of the self-employment rate as the number of successes (the number of self-employed immigrants), while the denominator represents the number of trials (the active immigrant population, which includes the self-employed, the wage-employed, and the unemployed). Our model can then be written as:

$$
\begin{aligned}
y_{i} & =f\left(\alpha+\beta_{1} H H I_{i}+\beta_{2} D_{1, i}+\beta_{3} D_{2, i}+\sum_{k} \gamma_{k} X_{k, i}\right)+\varepsilon_{i} \\
& =\frac{1}{1+e^{-\left(\alpha+\beta_{1} H H I_{i}+\beta_{2} D_{1, i}+\beta_{3} D_{2, i}+\sum_{k} \gamma_{k} X_{k, i}\right)}}+\varepsilon_{i},
\end{aligned}
$$


where all symbols are as before.

We first estimate a standard logistic regression (Model (1)), whose results are reported in Table 4. The estimated coefficients for two of our key variables - the ethnic concentration variable and the dummy variable identifying local units dominated by a group of recent immigration - turn out to be non-significant, while the coefficient for linguistic proficiency is significant and of the expected sign (positive). The coefficients of the remaining variables are as expected (see below for further details). These results do not seem to support our hypothesis that ethnic concentration has a positive effect on self-employment rates of immigrants.

Table 4. Estimated Models

\begin{tabular}{lcc}
\hline Explanatory variables & $(1)$ & $(2)$ \\
\hline Ethnic concentration of immigrants (hhi) & 0.00 & $0.10^{* *}$ \\
Recent immigration dummy & 0.00 & $-0.09^{* * *}$ \\
Language proficiency dummy & $0.15^{* * *}$ & $0.13^{* * *}$ \\
& & $0.55^{* * *}$ \\
Share of immigrant active men & $0.77^{* * *}$ & -0.07 \\
Share of immigrant married & -0.10 & $-0.17^{* * *}$ \\
Share of immigrants with a non-perm. resid. permit & $-0.23^{* * *}$ & $0.38^{* * *}$ \\
Share of immigrant employed in services & $0.35^{* * *}$ & $11.06^{* * *}$ \\
Immigrant average age & $11.02^{* * *}$ & 0.76 \\
Immigrant average age`2 & 1.12 & $-0.36^{* * *}$ \\
Immigrant average family size & $-0.42^{* * *}$ & $0.39^{* * *}$ \\
Share of immigrants with a professional degree & $0.58^{* * *}$ & 0.04 \\
Share of immigrants with an academic degree & -0.03 & $-1.79^{* *}$ \\
Immigrant unemployment rate & $-2.29^{* * *}$ & $2.25^{* *}$ \\
Immigrant unemployment rate 2 & $1.45^{*}$ & $-0.21^{* * *}$ \\
Urban dummy: city & & $-0.10^{* * *}$ \\
Urban dummy: suburb & $-0.15^{* * *}$ & -0.03 \\
Minimum altitude & $-0.12^{* * *}$ & $-1.25^{* * *}$ \\
(Intercept) & $-0.09^{* * *}$ & 6547 \\
\hline AIC & $-0.86^{* * *}$ & -3255.53 \\
Log-likelihood & 12098 & $2368.1(2472)$ \\
Residual deviance (Residual degrees of freedom) & -6030.75 & $4176.1(2472)$ \\
\hline Notes: Signficance & &
\end{tabular}

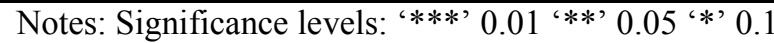

However, our results could be influenced by unobserved heterogeneity due to missing explanatory variables (for which variance is unknown). This is a common drawback of cross-sectional models. Therefore, we follow Patuelli et al. (2010) and apply a correction for so-called extra-binomial variation in logistic regressions by means of an overdispersion adjustment, which was originally suggested by Williams (1982) and provides a quasi-likelihood model estimate. More in detail, the method postulates 'a source of extra-binomial random variation between observations' (Williams, 1982, p. 144), and leads to an iterative estimation of the dispersion parameter associated with the data, with a concurrent adjustment of the regression weights. This estimation approach goes beyond the common practice of just computing so-called robust standard errors, since it also provides updated estimates of the regression coefficients.

Table 4 reports the results for the overdispersed logistic regression (Model (2)). As it can be seen from the diagnostics at the bottom of the table, the explanatory power of Model (2) represents a substantial improvement over Model (1). This is evident from the observation of Akaike's information criterion (AIC), whose value is approximately half of the previous one, from the residual deviance, as well as from the log-likelihood. The 
estimated coefficients now support our hypothesis that ethnic concentration and cultural diversity explain differences in self-employment rates.

The regression coefficient for the HHI is positive and significant, suggesting that highly concentrated ethnic communities provide more incentives or more favourable conditions for business ownership. This result suggests that the dominance of an ethnic group increases opportunities for social interaction within the group, thus raising potential for ethnic businesses. Since individuals prefer to build economic relationships with their peers, ethnic homogeneity may be seen as multiplying business opportunities. Furthermore, the positive coefficient for the HHI provides additional evidence for the presence of ethnic enclaves, where immigrants of the dominant group benefit from comparative advantages in serving the ethnic market.

The estimated coefficient for the recent immigration dummy variable turns out to be negative and highly significant, meaning that, if the locally dominant nationality is of recent immigration, self-employment among immigrants is lower. This result is consistent with our hypothesis that nationalities of latest immigration face more difficult conditions with regard to entrepreneurship (i.e., less integration and fragility).

Furthermore, the coefficient for the language proficiency dummy variable remains positive and significant, which means that local units with a dominant ethnic group belonging to the same linguistic group of the natives show higher self-employment rates. This result is in contrast with evidence collected in other countries, where linguistically isolated groups are found to be more likely to turn to self-employment in order to overcome discrimination and communication difficulties. We interpret the positive coefficient of the language dummy variable as an indication of the existence of a market effect, which produces more opportunities for immigrants speaking the language of the natives in serving the local markets.

The remaining estimated coefficients all have the expected signs and are significant, except for the share of married immigrants and for the share of academically educated people. In the case of the share of married immigrants, the non-significance of the finding could be due to information redundancy regarding the inclusion of the average family size or age, while for the case of academic education, language proficiency could be redundant. ${ }^{12}$ With regard to the remaining variables related to the characteristics of the immigrant community, the share of men is positively associated with self-employment, as well as their average age, which shows a linear behaviour (the quadratic term is non-significant). A higher share of immigrants with a non-permanent residence permit tends to reduce business ownership, since such immigrants do not plan to stay for a long time, or have just arrived. The coefficient for the share of immigrants employed in services is positive, suggesting that a sectoral composition of the local labour force favourable to the trade, sales, restaurant and hotel sectors encourages self-employment. As for the average family size, it tends to reduce local self-employment rates, most likely because of a stronger risk aversion. Immigrant communities with a large share of professionally educated people also show higher self-employment rates, supporting the hypothesis that higher educational attainments increase self-employment opportunities. The local unemployment rate has a strong negative effect on business ownership, meaning that immigrant communities with low unemployment rates experience high rates of immigrant self-employment. This result strengthens the market view hypothesis which suggests that low unemployment regions provide immigrants with potentially wider ethnic markets. Because we do not have income-related variables in our data set, unemployment may also be seen as a proxy for the general level of

12 The regression coefficient for academic education becomes marginally significant when language proficiency is excluded from the model. 
welfare of the local units. The coefficient estimated for the quadratic term of unemployment is also significant and positive, suggesting that the relationship between immigrant unemployment and self-employment rates is not linear, but $\mathrm{U}$-shaped. The nature of this relationship will be discussed in more detail below. The coefficients for the city and suburbs dummy variables are negative, suggesting that immigrant self-employment in Switzerland is not an urban phenomenon. This result is somehow surprising under the market view hypothesis (big cities, big markets), but is consistent with what we found for the ethnic concentration of immigrants. According to our findings, self-employment matters in concentrated immigrant communities, which are dominated by a traditional immigration nationality or by one nationality which is fluent in the host region's language. Typically, these characteristics are associated with the countryside, rather than with the major cities. Finally, the coefficient for the minimum altitude of each local unit turns out to be non-significant.

Because we estimated a nonlinear model (logistic regression), it may be interesting to observe how the effect of each of the explanatory variables on the dependent varies over their range, keeping all other variables constant at their representative values. Figure 5 shows the effect plots for selected explanatory variables, as well as the related 95 per cent confidence intervals (Fox, 1987, 2003). The predicted effect of the HHI is reported in Diagram (a), which highlights the positive association between local units characterized by a dominance of one or few ethnic groups and the self-employment rates of immigrants. The positive effects of both the share of immigrants employed in services and the share of professionally educated workers on the dependent variable are also clear in Diagrams (b) and (c), respectively. Diagram (d) provides additional evidence on the U-shaped relationship between unemployment and self-employment rates. An increase in the share of unemployed immigrants has a negative effect on the self-employment rate, which is evident in the lower part of the range, but becomes less relevant when the unemployment rate reaches 10 per cent.

\section{Conclusions}

In this paper, we estimated a model explaining the variation in the self-employment rates of immigrants in Switzerland in relation to ethnic concentration and cultural characteristics. In this regard, Switzerland is a particularly interesting case study: on the one hand, it has a large foreign working force; on the other hand, the self-employment rate of immigrants is much lower than the one of Swiss citizens, which is in contrast with evidence collected in other developed countries.

Using census data collected in 2000 for a cross section of 2,490 Swiss municipalities, we estimated a logistic regression model for the share of self-employed immigrants. We found that the local concentration of particular ethnic groups is a significant factor in increasing self-employment rates. Additionally, cultural characteristics were also found to be relevant. In particular, the proficiency of immigrants in the language spoken locally, as well as belonging to more traditional immigration waves, turned out to be associated with higher shares of selfemployment. Our results are relevant in particular from a policy-making viewpoint, since self-employment is seen as a useful way towards the integration of immigrants. On the one hand, we shall argue that the Swiss immigration policy, which at least until the 1990s aimed to limit the presence of immigrants and to strictly regulate their working conditions, has turned to be detrimental for the concentration of immigrants, and thus for their economic advancement. On the other hand, local authorities should now develop policies aiming to increase 
the immigrants' potential with regard to business ownership by favouring professional education, language proficiency and interaction within ethnic groups. Groups of recent immigration may deserve special consideration, since they appear to be less prone to business ownership.

(a)

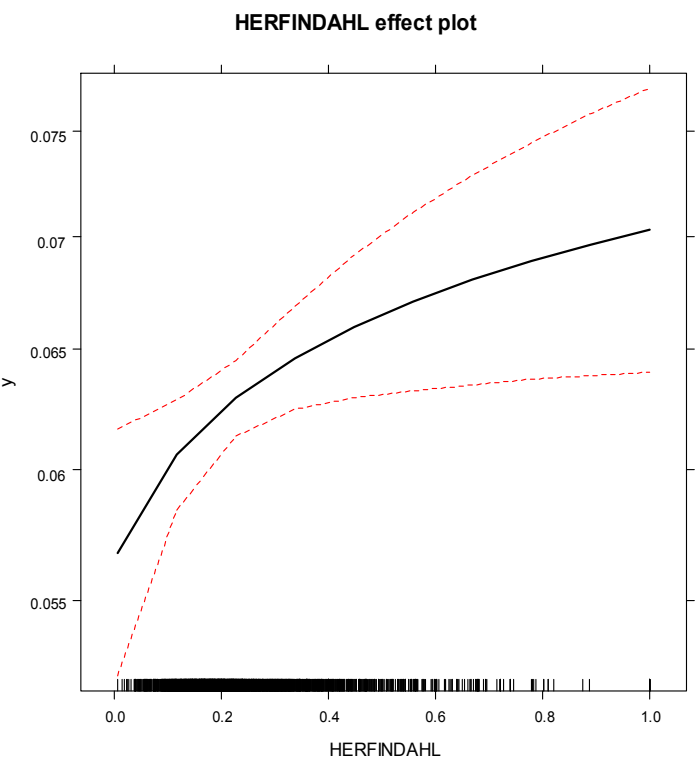

(c)

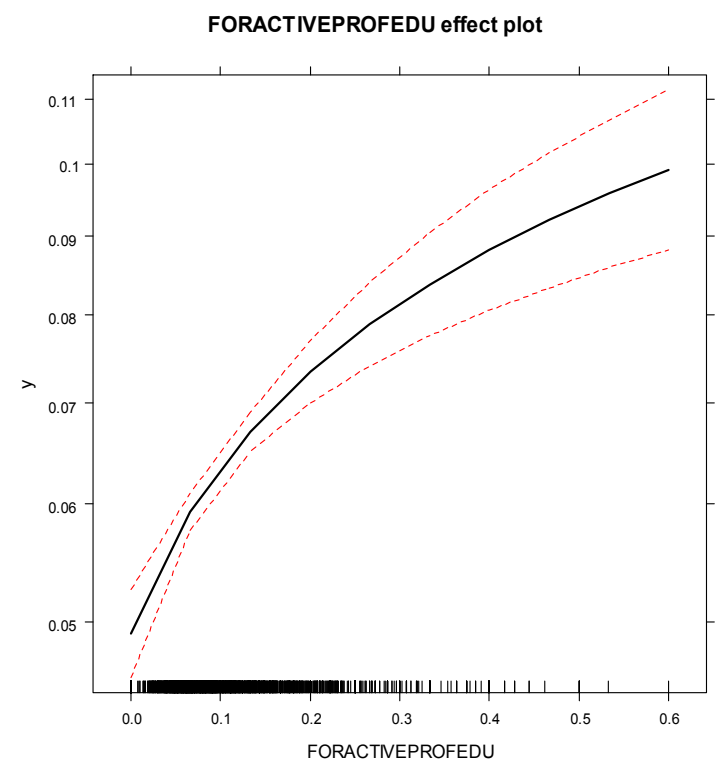

(b)

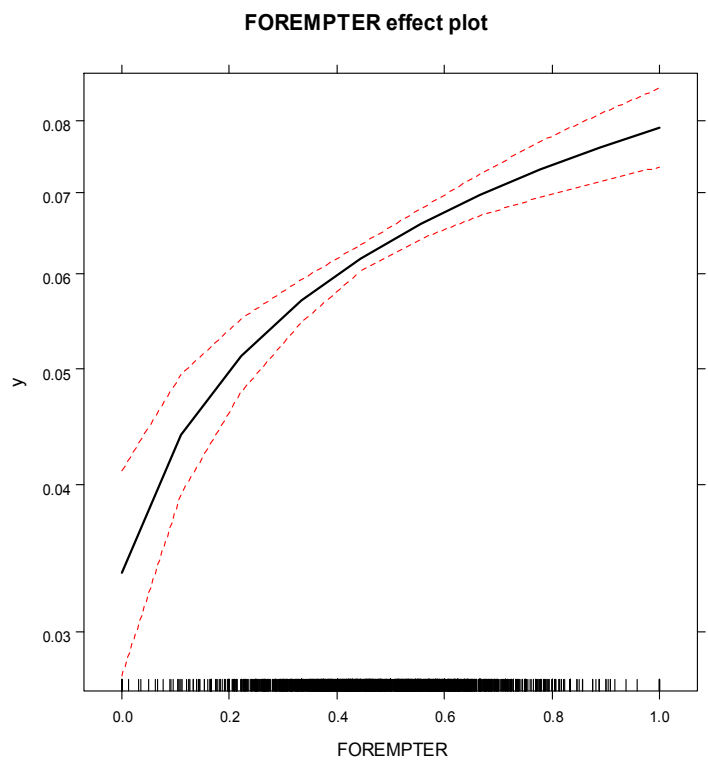

(d)

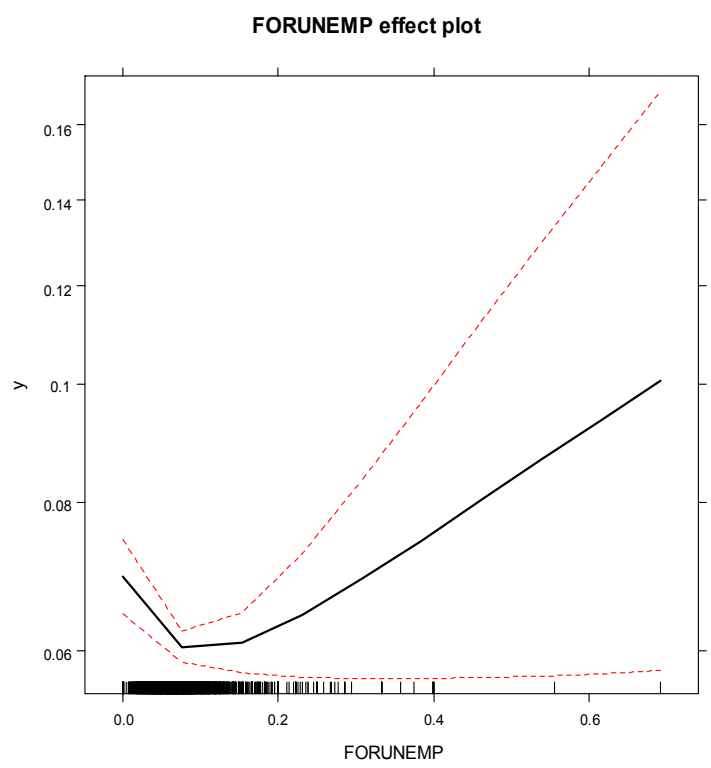

Figure 5. Effect plots for (a) HHI of ethnic concentration, (b) Share of immigrants employed in services, (c) share of immigrants with a professional degree and (d) immigrant unemployment rate. All variables to their original range

Future refinements of our model should also consider the differentials between immigrants and Swiss citizens in terms of self-employment, in order to filter out local conditions and specificities. In addition, spatial aspects should be investigated, in particular with regard to unobserved spatially correlated variables and spatial dependence. Finally, a more in-depth analysis, focusing on the behaviour of immigrants, could ideally be carried 
out using micro-level data, for example investigating imitation phenomena in space with respect to selfemployment.

\section{Acknowledgments}

The authors wish to thank Peter Nijkamp, Maria Abreu, Roger Bivand, Jason P. Brown, Simonetta Longhi, Enrique López-Bazo and Jacques Poot, as well as session participants to the 56th Annual North American Meetings of the Regional Science Association International (San Francisco, CA) and to the 'International Workshop on Migration Impact Analysis: New Horizons' (Amsterdam) for useful comments.

\section{Bibliography}

Aldrich, H. E., \& Waldinger, R. (1990). Ethnicity and Entrepreneurship. Annual Review of Sociology, 16(1), 111-135.

Aldrich, H. E., Cater, J., Jones, T., \& McEvoy, D. (1983). From Periphery to Peripheral: The South Asian Petite Bourgeoisie in England. Research in the Sociology of Work, 2, 1-32.

Alesina, A., \& La Ferrara, E. (2002). Who Trusts Others? Journal of Public Economics, 85(2), 207-234.

Alesina, A., \& La Ferrara, E. (2005). Ethnic Diversity and Economic Performance. Journal of Economic Literature, 43(3), 762-800.

Bates, T. (1994). Social Resources Generated by Group Support Networks May not be Beneficial to Asian Immigrant-Owned Small Businesses. Social Forces, 72(3), 671-689.

Bloom, D. E., Grenier, G., \& Gunderson, M. (1995). The Changing Labour Market Position of Canadian Immigrants. The Canadian Journal of Economics / Revue canadienne d'economique, 28(4b), 987-1005.

Bonacich, E. (1973). A Theory of Middleman Minorities. American Sociological Review, 38(5), 583-594.

Borjas, G. J. (1986). The Self-Employment Experience of Immigrants. The Journal of Human Resources, 21(4), 485-506.

Clark, K., \& Drinkwater, S. (2000). Pushed out or Pulled in? Self-Employment among Ethnic Minorities in England and Wales. Labour Economics, 7(5), 603-628.

Evans, M. D. R. (1989). Immigrant Entrepreneurship: Effects of Ethnic Market Size and Isolated Labor Pool. American Sociological Review, 54(6), 950-962.

Evans, M. D. R., \& Kelley, J. (1986). Immigrants' Work: Equality and Discrimination in the Australian Labour Market. Journal of Sociology, 22(2), 187-207.

Fairlie, R. W., \& Meyer, B. D. (1996). Ethnic and Racial Self-Employment Differences and Possible Explanations. The Journal of Human Resources, 31(4), 757-793.

Fluckiger, Y., \& Zarin-Nejadan, M. (1994). The Effect of Macroeconomic Variables on the Distribution of Income: The Case of Switzerland. Journal of Income Distribution, 4(1), 25-39.

Fox, J. (1987). Effect Displays for Generalized Linear Models. Sociological Methodology, 17, 347-361.

Fox, J. (2003). Effect Displays in R for Generalised Linear Models. Journal of Statistical Software, 8(15), 1-27.

FSO. (2000). Federal Population Census: FSO.

FSO. (2001). Limites Communales Généralisées, Niveau 3: Géodonnées: FSO.

FSO. (2004). Les Niveaux Géographiques de la Suisse 2000: FSO.

Glaeser, E. L., Laibson, D. I., Scheinkman, J. A., \& Soutter, C. L. (2000). Measuring Trust. Quarterly Journal of Economics, 115(3), 811-846.

Glocker, D., \& Steiner, V. (2007). Self-Employment: A Way to End Unemployment? Empirical Evidence from German Pseudo-Panel Data (Discussion Paper No. 2561). Berlin: DIW.

Gross, D. M. (2006). Immigration Policy And Foreign Population In Switzerland (Wold Bank Research Working papers No. 3853). Washington, D.C.: Wold Bank.

Herfindahl, O. C. (1950). Concentration In The Steel Industry. Unpublished Ph.D. Thesis, Columbia University, New York. 
Hirschman, A. O. (1945). National Power and the Structure of Foreign Trade. Berkeley Los Angeles London: University of California Press.

Kim, K. C., \& Won Moo, H. (1985). Ethnic Resources Utilization of Korean Immigrant Entrepreneurs in the Chicago Minority Area. International Migration Review, 19(1), 82-111.

Lazear, Edward P. (1999). Culture and Language. Journal of Political Economy, 107(S6), S95-S126.

Le, A. T. (2000). The Determinants of Immigrant Self-Employment in Australia. International Migration Review, 34(1), 183-214.

Light, I. H. (1972). Ethnic Enterprise in America: Business and Welfare among Chinese, Japanese, and Blacks. Berkeley: University of California Press.

Light, I. H. (1979). Disadvantaged Minorities in Self-Employment. International Journal of Comparative Sociology, 20(1), 31-45.

Mohl, R. A. (1983). An Ethnic "Boiling Pot": Cubans and Haitians in Miami. Journal of Ethnic Studies, 13(2), 51-74.

Noorderhaven, N. G., Wennekers, A. R. M., Hofstede, G., Thurik, A. R., \& Wildeman, R. E. (1999). SelfEmployment out of Dissatisfaction: An International Study (TI Discussion Paper No. 99-089/3). Rotterdam: Tinbergen Institute.

OECD. (2009). OECD Factbook 2009: Economic, Environmental and Social Statistics: OECD.

Patuelli, R., Griffith, D. A., Tiefelsdorf, M., \& Nijkamp, P. (2010). Spatial Filtering and Eigenvector Stability: Space-Time Models for German Unemployment Data. International Regional Science Review, (forthcoming).

Portes, A., \& Zhou, M. (1996). Self-Employment and the Earnings of Immigrants. American Sociological Review, 61(2), 219-230.

Reimers, C. W. (1983). Labor Market Discrimination Against Hispanic and Black Men. The Review of Economics and Statistics, 65(4), 570-579.

Sanders, J. M., \& Nee, V. (1996). Immigrant Self-Employment: The Family as Social Capital and the Value of Human Capital. American Sociological Review, 61(2), 231-249.

Williams, D. A. (1982). Extra-Binomial Variation in Logistic Linear Models. Applied Statistics, 31(2), 144-148.

Wong, B. P. (1988). Patronage, Brokerage, Entrepreneurship, and the Chinese Community of New York. New York: Ams Press.

Yoon, I.-J. (1991). The Changing Significance of Ethnic and Class Resources in Immigrant Businesses: The Case of Korean Immigrant Businesses in Chicago. International Migration Review, 25(2), 303-332.

Yuengert, A. M. (1995). Testing Hypotheses of Immigrant Self-Employment. The Journal of Human Resources, $30(1), 194-204$.

Zhou, M. (2004). Revisiting Ethnic Entrepreneurship: Convergencies, Controversies, and Conceptual Advancements. International Migration Review, 38(3), 1040-1074. 


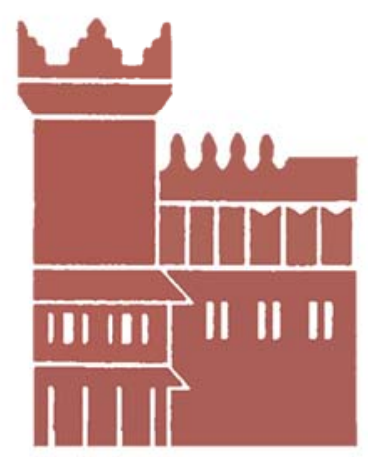

Alma Mater Studiorum - Università di Bologna DEPARTMENT OF ECONOMICS

Strada Maggiore 45

40125 Bologna - Italy

Tel. +39051 2092604

Fax +390512092664

http://www.dse.unibo.it 